\title{
Plasma proteins of young African catfish (Clarias gariepinus, Burchell 1822)
}

\author{
J. H. Boon ${ }^{1}$, J. M. Smits ${ }^{1}$, Th. Wensing ${ }^{2}$ and E. Lo ${ }^{1}\left({ }^{1}\right.$ Department of Fish Culture \\ and Fisheries, Wageningen Agricultural University, P.O. Box 338, 6700 AH Wa- \\ geningen, Netherlands, ${ }^{2}$ Clinic for Large Animal Medicin, Veterinary Faculty, \\ State University, Utrecht, Netherlands)
}

Received 20 March 1987; accepted 13 May 1987

\begin{abstract}
The effect of feeding level and water supply on the total plasma protein (T.P.P.) and fractions of these proteins (P.P.F.) of young African catfish (Clarias gariepinus, Burchell 1822) was studied. It was found that T.P.P. can be divided into four distinct fractions (P.P.F. I-IV) of which P.P.F. I is predominant. Analysis of the results shows a strong effect of feeding level on T.P.P. and P.P.F. I-IV. There was a positive correlation between T.P.P. and the weight of P.P.F. I-IV and a negative correlation between P.P.F. I and P.P.F. II. P.P.F. I might be usuable as an indicator for the health status of young Clarius gariepinus.
\end{abstract}

Key words: Clarias gariepinus, plasma proteins, electrophoresis, feeding level, water flow rate

Introduction. In mammalian farm animals and poultry different health monitoring programmes are available with various (blood) parameters to assess animal health (Blackmore, 1986). In fish health research the need to use such parameters has been underlined in a review by Blaxhall (1972). However, interpretation of the results of the investigations are difficult because of the usually large variations of values of parameters used between and within fish populations. Main sources of such variations are differences in feeding level and genetic and environmental factors. In intensive recirculation systems as used in the Netherlands variation in environmental conditions might be less, facilitating the use of blood parameters to estimate fish health.

The present study was carried out to quantify the plasma proteins of young African catfish and to study their relation with feeding level and water flow rate as part of a study on feeding level-dependent incidence of the Ruptured Intestine Syndrome of unknown etiology (RIŚue) (Boon et al., 1987).

Material and methods. Larvae, full sibs, obtained by artificial reproduction (Hogendoorn \& Vismans, 1980) were kept in aquaria placed in a recirculation system (Boon et al., 1987). On day 9 after hatching 15 groups of 300 larvae each were formed and each group was allocated to one out of three feeding levels, i.e. 1,2 and 3 times optimally, which were fed from day 9 after hatching onwards and might in- 
duce RISue. Within each feeding level the aquaria were randomly allotted to one out of five water flow rates: $1,2,3,4$ and $5 \mathrm{~min}^{-1}$ respectively. The experiment expired at the end of the 12th, 9th and 8th week after hatching when the incidence of RISue decreased to a low level and mean fish weight was $11.0,12.0$ and $13.5 \mathrm{~g}$ of feeding level 1, 2 and 3 respectively (Boon et al., 1987). On the last experimental day 10 fish per group were blood-sampled from the Vena caudalis with a heparinized syringe. Blood was centrifuged during 5 minutes at $4000 \mathrm{rpm}$ and plasma was stored at $-70{ }^{\circ} \mathrm{C}$ till examination for total plasma proteins (T.P.P.) and plasma protein fractions (P.P.F.). T.P.P. was measured in duplo with the biuret method (Gornall et al., 1949). Electrophoresis of plasma samples was done by using cellulose acetate paper in a Boskamp electrophoresis chamber powered with a Boskamp Pherostat 273.

The influences of feeding level and water flow rate on the various parameters were statistically analysed by using the BMPD $2 \mathrm{~V}$ program (Dixon et al., 1983). Also Pearson coefficients of correlations were calculated.

Results. The mean content of T.P.P. was $26-45 \pm 4.56 \mathrm{gl}^{-1}$. Electrophoresis clearly showed that plasma protein can be divided into four distinct fractions, P.P.F. I, II, III and IV (Fig. 1). With relation to the plasma proteins there seemed to be two different types of fish. One type with a high P.P.F. I $(>50 \%)(n=96)$ and another with a low P.P.F. I $(<50 \%)(n=14)$. Fish of the latter group had a high P.P.F. II

A.

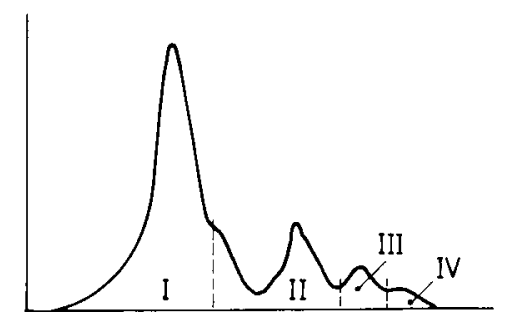

B.

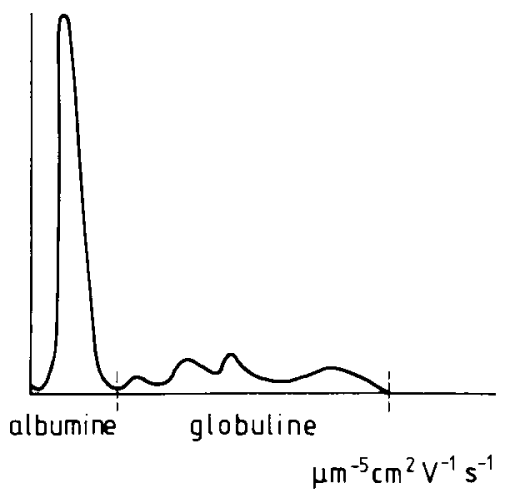

Fig. 1. Cellular acetate electropherogram of plasma proteins of larvae of African catfish (Clarias gariepinus) (A) and a human reference electropherogram obtained under the same conditions (B). 
and showed clinical signs of RISue. Compared to human reference plasma proteins there was a shift to the right side.

The analysis of variance showed a strong effect of feeding level on T.P.P. and P.P.F. I-IV $(P<0.02)$. There was no significant influence of water supply on them. Significant correlations between T.P.P. and the weights of the P.P.F. I-IV have been found $(r=0.78,0.57,0.38$ and 0.29 respectively; $P<0.05)$. Weights of P.P.F. I and II were negatively correlated $(r=-0.73, P<0.05)$.

Discussion. The electrophoretic patterns observed are more similar to those of man than to those of other fish species. This is in agreement with the findings of Boomker $(1979,1980)$. However the plasma proteins of Clarias gariepinus have a lower speed than those of mammals (Corbell, 1975; Moore, 1945), which ask for a longer running time.

T.P.P. levels measured in this experiment are lower than those found in most other investigations. Hattingh (1972) found in C. gariepinus $38.40-58.20 \mathrm{~g} \mathrm{I}^{-1}$. These values are in the same range as those found in other animals. The low values of the present study may be caused by the fish age (Moore, 1945; Blaxhall, 1972; Hille, 1982) in spite of the fact that Hattingh could not prove this relation.

The relative content of P.P.F. I is remarkably high. In the T.P.P. this fraction is much smaller in other fish species. In contrast to this, the part of P.P.F. IV is small compared to other fish species. Both may be influenced by the age of the experimental fish. P.P.F. I includes carrying proteins which are very useful in young growing fish. Under the experimental conditions the fish was not in contact with pathogens as present under practical circumstances in older fish. So the immune system was not stimulated resulting in a low level of immunoglobulins which are part of the P.P.F. IV (Craig \& Clem, 1983; Hille, 1982; Post, 1966). The moderate negative relationship found between P.P.F. I and II suggests they might be complementary proteins. P.P.F. IV seems to be kept at a constant level as is shown in earlier experiments with carp kept under various conditions (Boon et al., 1986). This results in a low correlation with the other parameters and a low effect of the feeding level on the P.P.F. IV. Therefore, despite the importance of P.P.F. IV for fish health, it is less suitable as an indicator for the health status of young C. gariepinus compared to the P.P.F. I, which shows a big variation and a good relation with the other parameters. This is supported by the difference in percentage of P.P.F. I found between C. gariepinus with symptoms of RISue and fish without.

\section{References}

Blackmore, D. J., 1986. The laboratory detection of subclinical disease. Proceedings IVth International Symposium of Veterinary Laboratory Diagnosticians (Amsterdam, 2-6 June 1986): 446-461.

Blaxhall. P. C., 1972. The haemotological assessment of the health of freshwater fish: a review of selected literature. Journal of Fish Biology 4: 593-604.

Boomker, J., 1979. The haemotology and histology of the haemopoetic organs of South African fresh water fish. I. The Haemopoetic organs of Clarias gariepinus and Sarotherodon mossambicus. Onderstepoort Journal of Veterinary Research 46: 217-222.

Boomker, J.. 1980. The haemocytology and histology of the maemopoetic organs of South African fresh water fish. II. Erythocytes and thrombocyts of Clarias gariepinus and Sarotherodon mossambicus. Onderstepoort Journal of Veterinary Research 47: 95-10. 
Boon, J. H., Th. Wensing \& L. T. N. Heinsbroek, 1986. Electrophoretic investigations of plasma proteins of carp (Cyprinus carpio L.) in relation to environmental and physiological factors. Proceedings IVth International Symposium of Veterinary Laboratory Diagnosticians (Amsterdam, 2-6 June 1986): 432-435.

Boon, J. H., R. Oorschot, A. M. Henken \& J. H. van Doesum, 1987. Ruptured Intestine Syndrome of unknown etiology of young African catfish. Aquaculture 63: 283-300.

Corrbell, M. J., 1975. The immune response in fish. A review. Journal of Fish Biology 7: 539-563.

Craig, J. L. \& L. W. Clem, 1983. Distinctive subpopulations of catfish serum antibody and immunoglobulin. Molecular Immunology 20(8): 811-818.

Dixon, W. J., M. B. Brown, L. Engelman, J. W. Frane, M. A. Hill, R. I. Jennrich \& J. D. Toporek, 1983. Statistican Software. University California Press, Berkeley, Los Angeles and London, $334 \mathrm{p}$.

Gornåll, A. G., C. J. Bardawill \& M. M. David, 1949. Determination of serum proteins by means of the biuret reagent. Journal of Biological Chemistry 177: 751.

Hattingh, J., 1972. Observations in the blood physiology of five South African fresh water fish. Journal of Fish Biology 4: 555-563.

Hille, S., 1982. A literature review of the blood chemistry of rainbow trout, Salmo gairdneri Rich. Journal of Fish Biology 20: 535-569.

Hogendoorn. H. \& M. M. Vismans, 1980. Controlled propagation of the African catfish, Clarians lazera (C\&V). II. Artificial reproduction. Aquaculture 21:39-53.

Moore, D. H., 1945. Species differences in serum protein patterns. Journal of Biological Chemistry 161: $21-32$.

Post, G., 1966. Serum proteins and antibody production in rainbow trout (Salmo gairdneri). Journal of the Fisheries Research Board of Canada 23(12): 1957-1967..

This synopsis is based on a student-thesis entitled 'Plasma-eiwitten bij jonge Clarias gariepinus (Burchell, 1822)'. Wageningen Agricultural University, Wageningen, 1986. 104 pp., 52 figs., 45 tables, 42 refs., 6 appendices. Dutch, English summary.

Available as paper copy (order R074P, $f 30$ including postage) or as microfiches (order R074M, f 17.50 including postage) at: NARD, clo Pudoc, P.O. Box 4, 6700 AA Wageningen, Netherlands (telex 45015 blhwg). 